\title{
The survey-based annual cycle of water temperature and the temperature of the maximum density in Lake Baikal
}

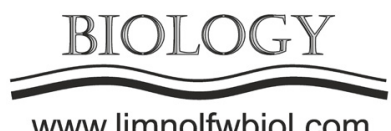

www.limnolfwbiol.com

\author{
Sherstyankin P.P.*, Potyomkin V.L., Kuimova L.N., Shimaraev M.N. \\ Limnological Institute, Siberian Branch of the Russian Academy of Sciences, Irkutsk, 664033, Russia
}

\begin{abstract}
Year-round hydrological studies of water temperature throughout the Baikal water column, which were conducted in 1973-1974, describe in a new way the methods for measuring the Baikal water temperature and the temperature of the maximum density (TMD). To highlight the TMD zone, we set some its limits, for example $\mp 0,25^{\circ} \cdot C \cdot t_{m d}+t_{m d}$. Notably, the spring thermal bar heats the water in the lake (the weather is calm): the thermal bar tends to maximum values and the autumn thermal bar, $\pm 0,25^{\circ} C \cdot t_{m d}+t_{m d}$, cools the water in the lake (the weather is stormy): the thermal bar tends to its minimum values.
\end{abstract}

Keywords: temperature, temperature of the maximum density (TMD), spring and autumn thermal bar, homothermy.

\section{Introduction}

Year-round hydrological studies of water temperature throughout the Baikal water column, which were conducted in 1973-1974, describe in a new way the methods for measuring the Baikal water temperature and the temperature of the maximum density (TMD).

\section{Materials and methods}

Based on J.R. Roebuck (1913), G.Yu. Vereshchagin (Vereshchagin, 1929) determined the values for "the temperatures of the maximum water density with accuracy, at which hundredths of a degree cannot be considered true". We used the works that studied TMD with accuracy to the fourth decimal place (Sherstyankin et al., 2000; Sherstyankin and Kuimova, 2009) and obtained new data. To highlight the TMD zone, we set some its limits, for example $\mp 0,25^{\circ} \cdot C \cdot t_{m d}+t_{m d}$. Notably, the spring thermal bar heats the water in the lake (the weather is calm): the thermal bar tends to maximum values (Sherstyankin,1964; Sherstyankin and Kuimova, 2009), and the autumn thermal bar, $\pm 0,25^{\circ} C \cdot t_{m d}+t_{m d}$, cools the water in the lake (the weather is stormy): the thermal bar tends to its minimum values.

Solar radiation also has the maximum and minimum in the annual cycle and depends on the height of the Sun (Kondratiev, 1965). According to the calculations of (Stepanova and Sherstyankin, 1984), the spectral distribution of solar radiation, taking into account albedo, leads to the maximum photosynthetically active radiation (PAR) of 44.41 $\mathrm{mW} / \mathrm{cm}^{2}$ on 20 June and the minimum PAR of 11 $\mathrm{mW} / \mathrm{cm}^{2}$ on 20 December, which corresponds to the available data.

\section{Results and discussion}

The annual cycle begins in late February-early March, lagging behind the onset of the increase in solar radiation (20 December) by more than two months. We discuss the winter survey of 1973 , which began on 17 February 1973 from Northern Baikal and then took place in Central and Southern Baikal until 7 March. Salinity was considered average throughout Lake Baikal and was $0.069 \mathrm{mg} / \mathrm{kg}$. The stations had all the features of the diurnal cycle: wave mixing subzones (diurnal convection) and the thermocline. The deepest position of TMD at a depth of $250(-150,+350) \mathrm{m}$ (Vereshchagin, 1936), was observed for Southern Baikal on 6-7 March when the water temperature in the hole was $0.1-0.12{ }^{\circ} \mathrm{C}$. Further, the water temperature gradually "dissolved" into a single convective layer, and by the onset of the spring homothermy on 6-8 July, the water temperature in the layer of $0-250 \mathrm{~m}$ was $3.74-3.6^{\circ} \mathrm{C}$. Weather during the spring homothermy is as follows: low wind and calm; water mass heats owing to the volumetric absorption (Boyarinov and Petrov, 1991) caused by the minimum spectral absorption in the PAR area and absorption coefficient approaching zero $(-\alpha \rightarrow 0)$. Horizontal movements turn into vertical ones (ca. 1 $\mathrm{m}$ wide) in the front of thermal bar, and homothermy 
becomes possible with complete calm (Sherstyankin, 1964). When $\lim t_{m d} \rightarrow t_{m d}$ ends, $t_{m d}$ becomes complete, and $t_{m d}+0,25^{\circ} \mathrm{C}$ makes the necessary marks for the onset of the warming up of the lake and the slow collection of all the features of the diurnal course (Vereshchagin, 1929; Boyarinov and Petrov, 1991). The August surveys yielded the results for the 0-300m layer: $9.12-6.79^{\circ} \mathrm{C}$ and $3.54-3.5$. The survey yielded the maximum results on 12-19 September for the 0-50m layer: $11.48-4.02,12.42-4.15$ and $13.51-3.93^{\circ} \mathrm{C}$. A reduction of solar radiation decreases the temperature of water masses. The October surveys (5-9, 11-14, 1423 October) revealed that the upper layer from 0 to $25 \mathrm{~m}$ was more homogeneous: 6.43-6.17; 6.6-6.53 and $6.75-6.17^{\circ} \mathrm{C}$, and became greater than the temperature in the same layers of $700 \mathrm{~m}, 600 \mathrm{~m}$ and $300 \mathrm{~m}$ in each Baikal basin. During the November surveys (1214, 14-21 and 16-18 November), the autumn thermal bar was almost covered from 0 to $100 \mathrm{~m}$ and from 0 to $200 \mathrm{~m}$ in the first two basins. The thermal bar was also in the northern basin. The autumn homothermy: weather conditions are storm winds; water cools; in the radiation area, PAR is minimum (Stepanova and Sherstyankin, 1984); forced convection (wind) deepens the autumn thermal bar (Shimaraev and Granin, 1991). The December surveys $(8,9 ; 10,11$ and $12-15$ December) indicated that southern basin cools slower: $3.36 ; 2.92$ and $2.01^{\circ} \mathrm{C}$. The autumn homothermy: weather conditions are storm winds; water cools; in the radiation area, PAR is minimum (Stepanova and Sherstyankin, 1984); forced convection (wind) deepens the autumn thermal bar (Shimaraev and Granin, 1991). The temperature becomes less than $4^{\circ} \mathrm{C}$ (the coefficient of thermal water expansion $+\alpha \rightarrow 0, \alpha=0,-\alpha<0)$; it cannot occur without wind (Shimaraev and Granin, 1991). This also concerns the inverse stratification: the temperature decreases, $\lim \left(t_{m d}-t\right) \rightarrow t_{m d}$, and $t_{m d}$ moves from the temperature of $3.96^{\circ} \mathrm{C}$ to $0^{\circ} \mathrm{C}$.

The surveys in February and March (13-19 March, 8,9 March and from 27 February to 6 March 1974) revealed $0.21,0.52$ and $0.1{ }^{\circ} \mathrm{C}$, indicating that in Southern and Central Baikal the onset of the annual cycle already took place, and in Northern Baikal, it only began.

The Baikal data can be used with the initial data on the TMD fields $\left(0 \mathrm{~m} ; 3.71-3.96-4.21^{\circ} \mathrm{C}\right)$ and final ones $\left(1600 \mathrm{~m}\right.$; $\left.0.44-0.69-0.94{ }^{\circ} \mathrm{C}\right)$ only during the spring heating and autumn cooling (thermal bar) from the surface to $400 \mathrm{~m}$ depth.

We briefly described the temperature at deeper sites. At almost all stations of Southern, Central and Northern Baikal, the temperature was higher (1300 $\mathrm{m}, 3.39$ (3.36); $1500 \mathrm{~m}, \mathbf{3 . 3 2}$ (3.16) and $800 \mathrm{~m} 3.43$ $(3.41)^{\circ} \mathrm{C}$.

\section{Conclusions}

Baikal water is known to have convective features. According to V.M. Sokolnikov (1964), raising or lowering of the zero boundary of TMD plays the main role: even a slight increase in $t_{m d}=3.98^{\circ} \mathrm{C}$ leads to $t>3.98^{\circ} \mathrm{C}$, i.e. an increase in heat is the intrinsic heat of the geoid, or the globe, which comes from the Earth, and a decrease in heat, a decrease in $t_{m d}$, is a cold of the surrounding space.

\section{Acknowledgements}

The work was carried out within the state task № 0345-2019-0008 “Assessment and prognosis of the ecological state of Lake Baikal and adjacent territories under conditions of anthropogenic impact and climate change".

\section{References}

Boyarinov P.M., Petrov I.P. 1991. Protsessy formirovaniya termicheskogo rezhima glubokikh presnovodnykh vodoyomov [The processes of formation of the thermal regime in deep freshwater bodies]. Leningrad: Nauka. (in Russian)

Kondratiev K.Ya. 1965. Aktinometriya [Actinometry]. Leningrad: Gidrometizdat. (in Russian)

Kuimova L.N., Sherstyankin P.P. 1992. Estimation of compaction during water mixing in fresh water bodies. Doklady Akademii Nauk [Academy of Sciences Reports] 325(1): 159-163. (in Russian)

Roebuck J.R. 1913. The reversible adiabatic expansion of water. Physical Review 2(4): 299-306.

Sherstyankin P.P. 1964. Dinamika vod Selenginskogo melkovodiya $\mathrm{v}$ nachale leta po dannym o raspredelenii opticheskikh kharakteristik i temperatury vody [Water dynamics of the Selenga shallow water in early summer according to the distribution of optical characteristics and water temperature]. Trudy Limnologicheskogo instituta SO AN SSSR [Proceedings of Limnological Institute SB USSR AS] 5(25): 29-37. (in Russian)

Sherstyankin P.P., Kuimova L.N. 2009. The vertical stability and the Väisälä-Brent frequency in deep natural waters: case study Lake Baikal, Tanganyika and the World Ocean. Doklady Akademii Nauk [Academy of Sciences Reports] 429(5): 673-678. (in Russian)

Sherstyankin P.P., Kuimova L.N., Potyomkin V.L. 2000. The temperature of maximum density and thermobaric properties of deep fresh waters: case study Lake Baikal. Doklady Akademii Nauk [Academy of Sciences Reports] 375(1): 107-111. (in Russian)

Shimaraev M.N., Granin N.G. 1991. Temperature stratification and convection mechanism in Lake Baikal. Doklady Akademii Nauk [Academy of Sciences Reports] 321(2): 381-385. (in Russian)

Sokolnikov V.M. 1964. Techeniya i vodoobmen v Baikale [Currents and water exchange in Lake Baikal]. In: Trudy Limnologicheskogo instituta SO AN SSSR [Proceedings of Limnological Institute SB USSR AS]. Moscow-Leningrad, pp. 5-21. (in Russian)

Stepanova V.V., Sherstyankin P.P. 1984. Spektralnoye raspredeleniye summarnoy radiatsii $\mathrm{v}$ vidimoy chasti spektra na Baikale. Avtomatizatsiya limnologicheskikh issledovaniy i svetovoy rezhim vodoyomov [Spectral distribution of total radiation in the visible part of the spectrum on Lake Baikal. Automation of limnological studies and the light regime of water bodies]. Novosibirsk: Nauka. (in Russian)

Tikhomirov A.I. 1959. The thermal bar in the Yakimvar Bay in Lake Ladoga. Izvestiya VGO [Bulletin of All-Union Geographical Society] 91(5): 424-438. (in Russian)

Vereshchagin G.Yu. 1929. Nekotoryye dannyye o rezhime glubinnykh vod Baikala $\mathrm{v}$ rayone Marituya [Some data on the regime of deep Baikal waters in the Marituy area]. Trudy 
Komissii po Ozeru Baikal [Proceedings of the Lake Baikal Comission] 2: 77-138. (in Russian)

Vereshchagin G.Yu. 1936. Osnovnyie cherty vertikalnogo raspredeleniya vodnykh mass na Baikale [The main features of the vertical distribution of water masses in Lake Baikal]. In: Akademiku V.I. Vernadskomu $\mathrm{k}$ pyatidesyatiletiyu nauchnoy i pedagogicheskoy deyatelnosti [To Academician V.I. Vernadsky for the fiftieth anniversary of scientific and pedagogical activity]. The USSR Academy of Sciences Publishing House, pp. 1207-1230. (in Russian) 